\title{
Legal Treatment of Items
}

\author{
Phd. Adrian Leka \\ Faculty of Law, "Luigj Gurakuqi" Universitety \\ Email: leka-ad@live.com
}

\section{Doi:10.5901/ajis.2016.v5n3p173}

\begin{abstract}
Items in Albanian civil legislation and in romanistic family optics of law is in itself a historical overview of the basic legal Albanian current legislation. The topic itself aims to identify the current Albanian legislation, with the object of his study the legal position toward items, to highlight its evolution within the same kind and in that compared with the standards of modern European legislations of the same family, so romanistic family. We have chosen the legal position of the test items as laboratory test tubes of Albanian and foreign legislation, focusing mainly on several types of areas as: a) in the classification of items and b) in their legal regime. As stated cursory above, is seen lying in two plans, that of evolution within the same kind that has consisted in a survey of the legal position of items in the legislation Albanian yearsand in standardization plan of actual legislation taking as comparative benchmark the Italian civil law. With the purpose of gathering information is used the cognitive research method of collating and analyzing. Ideas about the design or formulation of a definition on the item have been different at different times in different jurisdictions. These different perceptions are also displayed in the Albanian legislation by political influence. These jurisdictions opted from the influence of preferential family of law at different times have brought a diversified treatment of this concept going from romanistic family of law in that of the socialist law family to return eventually to a Roman German conception of object.Items are subject of the real law.Item is the part of material nature, which meets two conditions:The first condition is the physical one, which means that this section shall be subject to the power of people and the second is the social condition, which means that this part of the nature at the same time should be the commodity,means that can be exchanged andeconomicly circulated. The meaning of the item and the goods is not identical.Marx emphasized that human work is a good, but according to the bourgeois law it is not also the item. In civil law, item is only the good.
\end{abstract}

\section{Distribution of Items According to Civil Legislation of Zog I}

President legislation period, and then the king Zog I, in general, was a law that had western leaning.Civil code of this period relied on the Napoleonic civil code (1804), which for the time it was a modern code, on which were also supported other countries for their civil legislation.French civil code itself relied on Corpus lurisCivilis, of the Emperor Justinian.So he belonged clearly to the romainstic family of law.Civil Code of the Zog I took effect in 1929, in the legal meaning of this code, considerations for items is in a close treatment, as item is everything that may form the subject of rights, but is part of the outside world that It can be subject to human power, and that can bring the one who has the power to exercise the right to a benefit or economic benefit ${ }^{[B}$ Balstar Benussi,1931].An important aspect of this definition is the fact the conception of the item as part of the external world, but with the condition; "that part of the outside world that to be considered item, should be possessed by man". Legislation of 1929 paid2[idem] great importance to the legal regulation of items, items category of movable and immovable property, where for classifying items of immovable and movable property, three criteria served:- nature of items, - their destination, - facility referred to it on the basis of Sections 774,787 on the Civil Code.The difference between these two types of items according to the Code of Zog I is based on their legal and physical quality as:embodiment, consumption, separability, recovery,immovability or properly belonging ratio as:heredity, private or public entities belonging.Another division that was made to the object in the civil code of Zog I was:consumable items (res quae usuconsumietur) and the non-consumable 3 [Sections 838,839], replaceable and irreplaceable items ${ }^{4}[$ Section 1290], items of divisible or not,simple or combined items, purchasable or not purchasable items, and the last classification the one of main and accessory items.

\subsection{Distribution of items by Albanian legislation during the popular power.}

Since the aim of this topic is to record the classification of items under the Albanian legislation it was unnecessary to highlight this subject in the period of World War II, where Albania was occupied for the following reasons; 
- Firstly the war set in secondary plan the civil legislation and there was not any visible development during this period in the civil law.

- Secondly during the occupation there were no alloys and concrete legislation.

- Thirdly, there was no genuine production in the field of civil law that is worth analyzing.

During the popular invasion (monist government), given the characteristics of this period also impacted by historical, ideological factors which had the impact on civil legislation and the classification of items, which are divided into two sub periods:

- The period of the liberation of the country in 1945 until 1982.

- The period from 1982 to 1991.

1.2 Classification and legal regime of the items in the early processes of democratization of the country from 1990 onwards.

With the political changes occurred in Albania by the end of 1990, it changed the concept for the property, its forms and types, which was also reflected in the classification and legal regime of items. Observing the specifics that represents this period, the treatment will be distinguished in two periods; in the period from 1990 until 1994 and from 1994 to nowadays.

\subsubsection{Classification and legal regime of the items for the period from 1990 to 1994.}

In 1990 with the beginning of democratic reform also changes were made in the form of ownership.In August of 1990 foreign capital investment were allowed and their activities were arranged by law5[Decree No.7406,date 31.07.1990]. Owners of items, therefore to the subjects of the right to ownership under this law, namely under its Article 11 , are the state, legal and physical individuals.Privatization of some branches may be made in special cases by law, private individuals, juristic and physical entities, domestic or foreign, can be transferred to the ownership or lease to other persons juridical or physical, domestic or foreign,enterprise, unit or different objects under a separate contract to be concluded between them.For the transfer of state property to private property established in the National Privatization Agency at the Council of Ministers.

\subsubsection{Classification and legal regime of the items since 1994 (New Civil Code) until nowadays.}

Since 1994 that New Civil Code of the Republic of Albania came out'[Law no 7850, dated 29.07.1994], entered into force a new set of laws to regulate the legal relations in the economic field as well as in other areas,reaching an extension of the legal framework in compare to that of before 1990,therefore a legal arrangement has been reached with regard to the legal regime of items.Civil Code gives the following definition of the thing: 'Item is anything thatcan constitute object of ownership or of any other real right ${ }^{7}$ [Article 141 of the Civil Code]'. The main classifications made to items in this Code are:

- Movable and immovable items ${ }^{8}$ [Article 142 of the Civil Code]. Immovable items are land, springs and streams of water of all kinds which are connected with land, buildings and floating constructions related to land, under the law is immovable object whatever is consistently and continuously with land or building.Movable assets are considered all those things that are not immovableassets and natural energies.

- Main items and accessories ${ }^{9}$ [Article 147 of the Civil Code]. By merging several items in a single item relationships of dependency arise between objects that join, where one is considered main and one accessory.Accessory are considered all movable items that are intended to serve consistently a key item or to decorate it.

- Simple items, combined items and collective items. The criteria for this division is the connection between the objects and economic criteria, simple are those items that are recognized as natural, combined items consisting of a plurality of simple items, collective items are considered assembly of items simple or compound from economic and social point of view, as things in themselves function,such as library which occurs in the doctrine of civil law ${ }^{10}[$ A.Shehu, Ownership 1998].

- Divisible and non divisible items. Items that have a natural ability to be divided into parts without breaking out of this division and without invreasing its natural value, are divisible and all other items referred to as non divisible.

- Replaceable items and irreplaceable (in gender and defined individually).Based on the ability that things have 
to take the place of one another and applies only to movable assets,as immovable objects always have a certain individuality and can not replace each other.Term used for this separation of sex and items individually defined.

- Consumable and non-consumableitems. Consumables items are the ones that break during use or lose their use, while the opposite occurs with non-consumable items.

- Other items classifications are, physical and non physical items.Such a division was made in Roman law and is accepted even today.Physical items are considered personal items that could be affected like liquids, energies, whereas non physical division are those that can not be affected but that are thought as the right to a name, intellectual productivity, etc.

- Purchasable or not purchasable items. Not purchasable items are all items that for various legal reasons or by the nature of the item can not be traded.

\section{A Brief Legal Treatment on the Classification and the Legal Regime of Items under the Italian Civil Legislation}

Italian legislation is a legislation with tradition in the field of civil law based in Corpus lurisCivilis and the Napoleonic Code (1804), is a legislation that belongs to the same family of law with our civil legislation, therefore to the romanistic civil law family,is a legislation which has served as a model for the construction of our civil legislation and along these reasons,also the comparison of standards of our legislation with the standards of the Italian one is more understandable and useful.

\subsection{Classification and judicial regime of the items under Italian civil law in force.}

Even in the Italian system of law the item is treated as an object of ownership. The rights over items that traditionally take the name of real rights (ius in re), in the Italian system of law are as follows:- ownership, - emphiteosis, - usufruct, - use, residential, - easement and the right over the area.

Ownership is the real right that allows a wider range of rights to be exercised on an item. The right of ownership has these two key elements ${ }^{11}$ [CEDAM,Milano,2001] , the opportunity to enjoy items which means possibility to use or notand the opportunity to own the item which is called the juristic availability opportunity that means you sell, donate, leave someone by the will.

Compared with ownership, six other real rights appear as:

- Limited rights or partial, usually presented by a possibility (right).

- Rights on someone else's belongings.

\subsection{Classification of items.}

Items according to Italian legislation have this important row of classification, items can be classified as:

- Items in ownership and items of anyone. This division is ancient and derived from the Roman law.

- Movable and immovable items

- Replaceable and irreplaceable items. The former belong to a group called items that can be replaced with other items, and the irreplaceable items are also called items determined individually.

- Consumableand non-consumableitems.

- Items in public ownership and private property items.This division is based on Article 42 of the Italian Constitution which states that the property is public or private, the economic benefits belong the state, etnities or privates. Public and private ownership do not deplete the possible forms of ownership.

\section{Legal Regime of Objects by the Italian Justice}

In the Italian law there is observed the same treatment as that made by our legislation to the concept of " item ".So in civil law, " item " can not be called the innumerable things of the world from which man can not benefit any avail, eg mineral resources of other planets. Item as a concept is historically considered relative and based on the peculiarities of the evolution of civilization. There are things that nature provides in abundance, in the Roman civilization they were called 'res communes omnium' so items belonging to all for the simple reason that nobody has an interest or capacity to decide with 
it a relation for time, by excluding all others from using these items.Article 810 of the Italian Civil Code gives a very narrow definition of the concept " item ": "Items are those that can form object of rights ".Whereas Article 814 goes on to clarify further the meaning of the Italian law on this concept by calling items'even the natural energies if they have economic value ".The report of human with the item is regulated by the right of property, as in any other system of law.Article 831 of the Italian Civil Code gives the definition of it as the right to enjoy and dispose of items in full exclusive.Also any system of law regulates the ownership disagreements between the people for the ownerships of the items defining ways of gaining the ownership. The principle that 'ownership is acquired only with the procedures laid down by law' sanctioned in Article 922 of the Italian Civil Code, establishes the category of public goods.In our times these goods belong to the state or public institutions, who have been charged with the task to discipline the use from all or to use in such a way as to benefit all.Public ownership may include the protection of nature or cultural ownership,it establishes limits to the property and imposes obligations to the owner.

\subsection{Observations on the vertical plane.}

In the context of classification and legal regime of the items in our legislation in the vertical plane of the study it has undergone quite a change.These changes have been subordinated, according to political changes.From what we saw recognize that civil legislation in Albania from the moment of formation of the state can be divided into four stages:

$>$ Civil legislation of Zog I which brought to the feudal Albania of that period a progressive legislation with western modern trend, where its models were the legislations of France and Italy.In the chapter of classification of the item and its legal regime we note a fairly modern and detailed treatment with a refined and excellent legal language where is evident the definite Western influence in this area.

$>$ In antithesis to this legislation delicate and complete, appears the legal framework of the first years of liberation in which is felt the politicization action with communist ideas which mainly aimed at reducing private property.The legal framework of at that time gave state and social owned property to the detriment of private property.

$>$ A period characterized by legislation with radical trend towards the disappearance of private property in the change of ownership types in favor of state property items diversification was the legal framework that accompanied the the Constitution of 12/28/1976 in the Civil Code of 1982the spirit of this constitution appeared clear and this legislation constitutes even the most radical.

$>$ Actual civil legislation is the result of a western trend the basis of which is the diversity of properties and legal protection of this diversity, the establishment of the state in the same level of protection in terms of individual securities, dissapearing in this way the preferential principle.

\subsection{Observations on the horizontal plane.}

Albanian civil legislation is a legislation that generally belongs to the romanistic family and in particular its normative part on the classification and legal regime of the items is quite similar to the Italian legislationthat was treated above, this happens because the Italian Civil Code of 1942 has been taken as a model for the design of the New Albanian Civil Code.Changes are few and they especially focus on the part that belongs to the legal regime of items.Although the definition of the concept is the same the definition of the immobile items varies slightly.In conclusion we can say that the Albanian civil legislation is enriched and continues to enrich with juridical rate, in order to achieve European standards. The last few years apart from the exit of the Civil Code in 1994,have been approved and entered into force a number of laws that supported and completed it further as eg;Law 'On Urban Planning' '1993,' 'On the restitution and compensation of property to former owners' 1993," Code of Pr. Civil " 1996, Law 8440, dated 13.01.1999,"For registration, use and control of vessels in 20NRT'. This does not mean that this process is over, but that this process is in the path of continuous improvement.

\section{Conclusions}

Just as noted in the introduction part the main point of this topic was the current Albanian legislation concerning the classification of the items and the legal regime,compared to the vertical plane, so in a retrospective treatment of the Albanian legislation in years and in the horizontal plane where the actual Albanian legislation is compared with a romanistic family legislation,closest to our legislation to see legal standards in the field of classifications and the legal 
regime of property.This last part consists of confrontation and conclusion for each case. The theme has been extended in two directions that of evolution within same kind,that consists on a survey of the legal position of the items in Albanian legislation through years,and in th plan of current standardization of the legislation taking as a comparative benchmark the Italian civil law.The aim was to identify the current Albanian legislation,with study object its legal position towards itemsto highlight its evolution within same kind and in that compared with European standards of modern legislation of the same family.

\section{References}

Alberto Trabucchi "Instituzioni di Diritto Civile" Giuffre Editore, Milano 1996.

Antonio Gambaro, "Il diritto di Propieta" Milano, Dott. Giuffre Editore 1995.

AvniShehu, Pronesia, SHBLU,Tirane 1998.

Baltasar Benussi, 'Items, possession and its modifications', Commentary to the Civil Code,1931.

Francesco Galgano, "Private Law' Luarasi, third edition, Tiranë.

MarjanaSemini" Law of Obligations and Contracts',Tiranë,1998.

Paskal Haxhi "'Legal regime of the land ',Tiranë,1998.

Pietro Riescigno "Manuale del diritto Privato Italiano",Jovene Editore, Napoli 1999.

Codice Civile, Giuffre Editore,Milano,2000.

Index of the legal acts of Albania, published in the official journal 1985-1993-1994.

Albanian Legislation Index 1990-2005, publications MORAVA.

Law on Legal Actions and Obligations in 1957.

Civil Code of RPSSH, 1981.

Civil Code of RA 1994 Law N0.7850 dated 9.07.1994.

The Civil Procedure Code of RA Law 8116 dated 03.29.1996.

Balstar Benussi "Items, possession and its modifications",Publication of the Ministry of Justice,1931 pg.3.

Sections 838,839 Civil Code of Zogu I, Publication of the Ministry of Justice.

Section 1290 of Civil Code of Zogu IYear 1929.

Decree No.7406,date 31.07.1990 "For the protection of foreign investments" and No.7407,date 31.07.1990 "For economic activity of companies with foreign capital participation in A.R ".

Civil Code was approved by Law no 7850, dated 29.07.1994

Article 141 of the Civil Code

Article 142 of the Civil Code

Article 147 of the Civil Code

Avni Shehu, Ownership, P.H Libri Universitar, Tiranë 1998, pg 10.

Article 822 of the Italian Civil Code, CEDAM,Milano,2001. 
